\title{
Erratum to: Regularities, laws, and an exceedingly modest premisefor a cosmological argument
}

\section{Travis Dumsday ${ }^{1}$}

Published online: 25 November 2016

(C) Springer Science+Business Media Dordrecht 2016

\section{Erratum to: Int J Philos Relig DOI 10.1007/s11153-016-9586-x}

In the original publication of this article, a portion of text that should have appeared in footnote \#15 was mistakenly removed and placed in the main text. The first paragraph of footnote \#15 ends with this sentence: "That is, one could deploy a modal version of the present argument, along the following lines:". Here there should have followed, in the same footnote, the eight-premise modal argument. That argument was mistakenly transferred to the main text.

The online version of the original article can be found under doi:10.1007/s11153-016-9586-x.

Travis Dumsday

Travis.dumsday@concordia.ab.ca

1 Canada Research Chair in Theology and the Philosophy of Science, Department of Philosophy \& Religious Studies, Concordia University of Edmonton, 7128 Ada Blvd., Edmonton, AB T5B 4E4, Canada 